\title{
Collaboration in Environmental Conflict Management and Decision-Making: Comparing Best Practices With Insights From Collaborative Learning Work
}

\author{
Gregg B. Walker ${ }^{1 *}$ and Steven E. Daniels ${ }^{2}$ \\ ${ }^{1}$ School of Communication, Oregon State University, Corvallis, OR, United States, ${ }^{2}$ Department of Sociology, Social Work, \\ and Anthropology, Utah State University, Logan, UT, United States
}

\section{OPEN ACCESS}

Edited by:

Tracylee Clarke

California State University, Channel

Islands, United States

Reviewed by:

Tarla Rai Peterson,

The University of Texas at El Paso,

United States

Deborah Cox Callister, University of San Francisco,

United States

*Correspondence:

Gregg B. Walker

gwalker@oregonstate.edu

Specialty section:

This article was submitted to Science and Environmental

Communication,

a section of the journal Frontiers in Communication

Received: 24 August 2018 Accepted: 18 January 2019

Published: 13 March 2019

Citation:

Walker GB and Daniels SE (2019) Collaboration in Environmental Conflict

Management and Decision-Making:

Comparing Best Practices With

Insights From Collaborative Learning

Work. Front. Commun. 4:2.

doi: 10.3389/fcomm.2019.00002
For much of the past three decades, when environmental or natural resource conflicts have emerged, diverse parties (government agencies, stakeholder organizations, and citizens) have often sought an alternative to adversarial battles. They have turned to collaboration, and in so doing, have attempted to work through conflicts to find common ground and make sound decisions. And in so doing their experiences have given rise to the development of "best practices" for conducting collaborative work. This essay considers three sets of best practices for collaboration and compares those practices with the "best practices" that the authors have determined from their 27 years of Collaborative Learning fieldwork. When insights from Collaborative Learning projects are combined with a collective set of best practices, 18 areas emerge to guide collaborative efforts.

Keywords: collaboration, collaborative learning, best practices, environmental policy, natural resource management, decision-making, stakeholder engagement

\section{INTRODUCTION}

In 1991, a forestry professor contacted a communication professor to ask about a course in "conflict management" that the communication professor was teaching. The forestry professor asked if he could sit in on the weekly evening class. The communication professor welcomed the forestry professor's participation. After the class, the two professors would often go to a nearby watering hole for beverages and conversation. During one of those conversations, the forestry professor asked the communication professor, "how interested are you in environmental issues?" The communication professor replied, "very much; but I only know about environmental issues as a layperson." The forestry professor, who was fielding phone calls about forest management controversies, responded, "that's OK, I don't need a person well-steeped in forest and environmental policy, I need to work with someone who understands conflict."

In that conversation a partnership between two professors-one from communication and one from forestry-was born. As the professors continued their watering hole conversations, they discovered a shared interest natural resource and environmental policy decision making, particularly the ways in which citizens were (and were not) involved in those decisions.

The Oregon State University professors met during a period of intense environmental conflict in the Pacific Northwest, particularly involving habitat for the Spotted Owl (Daniels and Walker, 2012). They noted that three factors characterized environmental conflicts, such as those involving the Endangered Species Act (e.g., the Spotted Owl): complexity, controversy, and uncertainty. 
The two professors from Oregon State University began to explore the feasibility of combining three distinct but well-established fields of practice: systems thinking to address complexity, public policy dispute resolution (conflict management, negotiation, and mediation) to engage controversy, and adult, experiential learning to confront uncertainty. The integration and implementation of these three areas-systems thinking, dispute resolution, and experiential learning-relied on participatory communication (Walker, 2007) to create a methodology that the professors named "Collaborative Learning," borrowing a term from the education field (Daniels and Walker, 1996, 2001).

Within a well-publicized and contentious situation involving salmon habitat, resource extraction, watershed health, and related issues, we (the two professors) designed and facilitated our first Collaborative Learning (CL) event in Spring 1992. A $7 \mathrm{~h}$ CL workshop took place full on the second day (a Saturday) of a 2 day Illinois River Symposium in southern Oregon, during which about 130 citizens and government agency staff generated about 150 improvement concepts (recommendations or action items). Since that time, we have conducted dozens of Collaborative Learning-based projects (assessments, trainings, and facilitated workshops) throughout the United States and have presented Collaborative Learning ideas internationally. Our students and colleagues have taken the CL method into other regions and issue domains, ranging from dairy management in Sweden to rural healthcare services in Wisconsin to water resource management in Texas to genetically modified crops in South Africa.

As of this writing -27 years since we began to construct the Collaborative Learning approach-we continue to apply, modify, and improve the CL methodology, both as a philosophy and through its techniques. In recent years we have brought CL concepts and tools into the work of the National Collaboration Cadre of the Forest Service of the US Department of Agriculture. We serve as the two "academics" on the Cadre team.

During the more than two and one-half decades of CL work, we have discovered other methods for collaborative stakeholder participation in environmental and natural resource policy decisions. Some have been developed by colleagues at university-based institutes (e.g., the Ruckelshaus Institute at the University of Wyoming), some by colleagues at public policy dispute resolution firms (e.g., the Boulder, Coloradobased CDR Associates), and others by colleagues who work as independent consultants.

Consequently, many people and organizations have contributed significantly to the field of collaborative environmental and natural resource policy decision making. As they have done so, as "collaborative process" academics, professionals, practitioners, and managers, they and their organizations may have contributed to the "best practices" movement. As collaborative process and planning efforts proliferated, organizations, and agencies sought to identify the "best practices" associated with collaboration. Although space constraints and the scope of this essay limit a review of these efforts, we want to acknowledge that "best practices" work has and will continue to evolve.
In this essay, we review some significant "best practice" efforts. We then compare the "best practices" of collaboration with our more than quarter century of field experience with Collaborative Learning. Prior to that discussion, we offer a short explanation of the Collaborative Learning approach. An extensive discussion of CL is in Working through Conflict: The Collaborative Learning Approach (Daniels and Walker, 2001).

The discussion of "best practices" is grounded in the significant work others have done in the area of natural resources and environmental policy conflict management and decisionmaking. Although not addressing best practices per se, authors writing in the 1980s (e.g., Bingham, 1986; Amy, 1987; Gray, 1989), the 1990s (e.g., Dukes, 1996; Susskind and Field, 1996; Cortner and Moote, 1998); the 2000s (e.g., Susskind et al., 2000; Wondolleck and Yaffee, 2000; Weber, 2003; Koontz et al., 2004; McKinney and Harmon, 2004), and this decade (e.g., Orr, 2014; Emerson and Nabatchi, 2015; Clarke and Peterson, 2016; Margerum and Robinson, 2016), have provided cases, presented concepts, and discussed policies and actions related to "what works" in the field. Much of this literature has influenced our ideas about collaboration, both before and since publishing Working Through Environmental Conflict.

One could review these publications and related to literature to assemble a compendium of best practices, but to do so is beyond the scope of this essay. The focus here is on three sets of best practices that have been developed and published, and to compare those best practices with what we have learned from almost three decade of field work.

\section{THE COLLABORATIVE LEARNING APPROACH-BRIEFLY ${ }^{1}$}

Although Collaborative Learning (CL) is a methodology appropriate for complex and controversial public policy situations, we developed it to address natural resource, environmental, and community conflict and decision-making situations. As noted earlier, we sought to create a method that accounted for complexity, controversy, and uncertainty (Walker et al., 2006a; Daniels and Walker, 2012).

In our book, Working through Environmental Conflict: The Collaborative Learning Approach (2 001), we defined Collaborative Learning as "a framework and set of techniques intended for multiparty decision situations... a means of designing and implementing a series of events (meetings, field trips, etc.) to promote creative thought, constructive debate, and the effective implementation of proposals that the stakeholders generate" (p. 15). In writing since, we have added that CL is also a philosophy; an orientation or view that conflicts can be managed, disputes resolved, and good decisions achieved through collaborative interaction. Furthermore, CL is not a consensus-based approach, although it welcomes consensus when it emerges from the collaborative interaction of the parties. Many natural resource and environmental policy conflict

\footnotetext{
${ }^{1}$ Portions of this discussions of Collaborative Learning have been adapted from Walker et al. (2006b) and Daniels and Walker (2012).
} 
situations as so complex and controversial that achieving comprehensive consensus decisions is an unrealistic goal.

Collaborative Learning is illustrated in Figure 1. To address complexity, Collaborative Learning has drawn ideas from systems thinking, especially soft systems methodology (Checkland and Scholes, 1990; Wilson and Morren, 1990). To deal with controversy, CL incorporates ideas from the alternative dispute resolution areas of conflict management, mediation and negotiation (e.g., Moore, 2014; Lewicki et al., 2015; Clarke and Peterson, 2016; Hocker and Wilmot, 2017). Uncertainty is addressed through experiential, adult learning (Senge, 1990; Kolb, 2015). Systems thinking, conflict management/dispute resolution practices, and uncertainty reduction are integrated through participatory communication (Walker, 2007). This dynamic learning approach emphasizes six fundamental principles with the pneumonic of FAAITH: fairness, accountability, access, inclusion, transparency, and honesty (Walker et al., 2007).

Collaborative Learning functions in three ways: (1) as a philosophy or orientation, (2) as a framework, and (3) as a set of tactics or techniques. The following characteristics of CL pertain to all three levels:

- Reframes the matter away from solving a problem to one of improving a situation.

- Views the situation as a set of interrelated systems, with an emphasis on human activity.

- Defines an improvement as a desirable and feasible (workable) change or action.

- Emphasizes that significant learning-about science, issues, and value differences-will have to occur before implementable improvements are possible.

- Considers communication as multi-faceted and dynamic, and that the meanings constructed are more important than the messages sent.

- (Walker et al., 2006b; see Daniels and Walker, 1996, 2001).

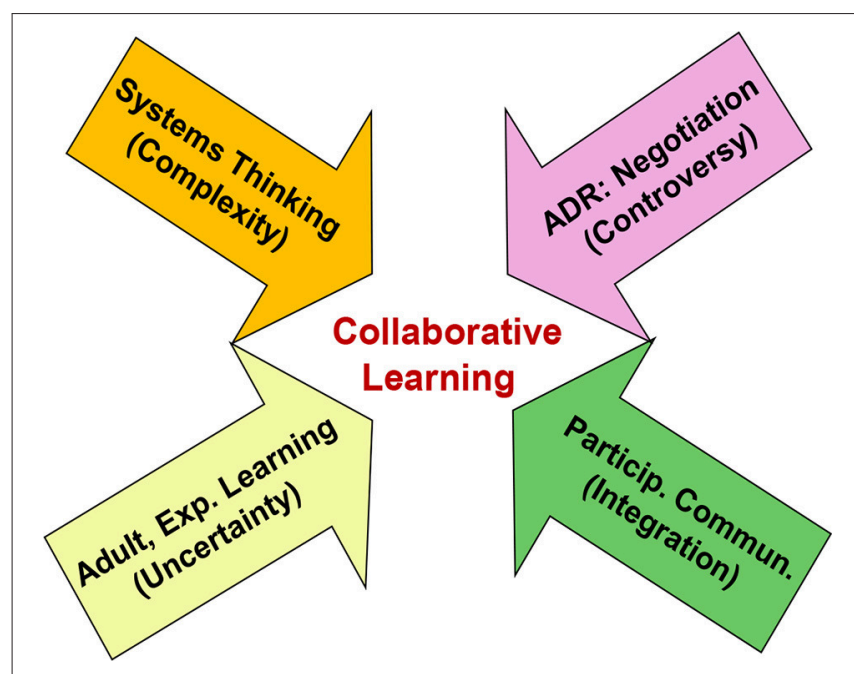

FIGURE 1 | Collaborative learning foundations. Daniels and Walker (2012).
Whether employed for stakeholder engagement (public participation) or as a guide for a planning or project team's work, Collaborative Learning encourages people to address conflict, think systemically, communicate openly, and learn from one another as they work though a challenging situation (Daniels and Walker, 2012; Walker et al., 2015).

A typical CL Project stakeholder engagement project involves assessment, training, and citizen workshops. A basic CL workshop design illustrates how the CL philosophy and its key concepts are enacted as part of a public participation strategy (Walker et al., 2006b). The first stages of a CL workshop, for example, emphasize common understanding. Activities might include information exchange, imagining best and worst possible futures, and visual representations of the situation, perhaps by using a "situation map," "generations wall," or similar systems tools (Daniels and Walker, 2001, 2012). In middle stages, CL participants focus on their concerns and interests regarding the specific problematic situation, and how their concerns and interests relate to those of other parties. With their concerns and interests as a foundation, CL parties identify possible changes that could be made: "situation improvements." In latter stages, the participants debate these improvements (sometimes labeled as action items or recommendations), addressing whether or not they represent desirable and feasible changes in the present situation (Walker et al., 2006b). Sets of improvements may be organized as action plans (Daniels and Walker, 2001). This CL approach-from concerns and interests to improvements and the evaluation of those improvements-involve both dialogue and deliberation. The deliberation component of the CL process reflects inter-based or mutual-gains negotiation (Fisher and Ury, 1991; Susskind and Field, 1996). Simply put, a CL workshop process progress from dialogue to deliberation to decision.

Throughout a typical CL workshop process, participants talk with and learn from one another in groups of various sizes. For example, a CL community workshop process will organize groups to discuss improvements. After each CL participant has developed an improvement, she or he discusses that improvement with a few other people. As they talk about each person's improvements, they are guided to evaluate feasibility and priority issues, thereby beginning to develop a collaborative action plan (Daniels and Walker, 2001; Walker et al., 2006b). These discussions feature participatory communication; active listening, questioning, and argument are respected. People clarify and refine their improvements through dialogue and deliberation. Collaborative Learning emphasizes "talking with" rather than "talking at" (Walker et al., 2006b).

A Collaborative Learning process calls on the relevant decision authority and convening organization(s), to participate, not as the facilitator or intermediary (e.g., arbitrator), but as a major player (Walker et al., 2006b). For example, a government agency such as the USDA-Forest Service may be the decision-maker in the problem situation (e.g., revising a forest management plan, developing a potential timber sale), but, within a CL process, does not function simply as an arbitrator or quasi-judge. Agency leaders clarify to both internal and external constituents the nature and scope of the decision space-what is on the 
table to be negotiated; where stakeholders' contributions my influence the outcome. Agency personnel participate in CL activities both as citizens and as representatives of the agency. Agency participants, just like others in the CL process, share their knowledge and expertise about the situation, ask questions, listen, and discuss the issues. Doing so does not compromise the agency's decision authority but respects allow agency personnel as active participants (Walker et al., 2006b). While this type of agency engagement may not be conventional or typical, it has been evident in CL projects (Walker et al., 2006b; see Daniels and Walker, 1996, 2001; Blatner et al., 2001).

Collaborative Learning presumes that situations are dynamic, systemic, and changing. CL is a framework that can be adapted to a particular situation to generate:

- Dialogue between diverse communities: scientific, public, administrative;

- Improved understanding of the specific problem situation;

- Integration of technical and traditional/public knowledge about the problem situation;

- Increased rapport, respect, and trust among participants;

- Clearly articulated systems-based concerns about the problem situation; and

- Tangible improvements in the problem situation. (Walker et al., 2006b).

Collaborative Learning, while beneficial within a complex and controversial policy situation, is no panacea or "quick fix." It is one of possibly many frameworks that can involve people in meaningful learning and discussion about challenging management and decision situations. It values emergent consensus but is not consensus-driven. It does stress learning, understanding, and the development of improvements (feasible, workable, implementable changes) in the situation (Walker et al., 2006b). CL does not foster the development of a "groupthink" (Janis, 1982). Rather, a CL process encourages parties to make progress and develop actions as they work through issues, values, concerns, and interests.

Like other collaboration methods, Collaborative Learning differs substantially from conventional public involvement (PI) approaches. Conventional public involvement privileges technical knowledge; CL respects and incorporates traditional (local, indigenous) as well. Conventional PI methods typically view learning as one-way with the purpose of "inform and educate;" CL emphasizes shared, mutual, on-going learning. Conventional PI tools, such as the public hearing, exhibit a "command and control" form of communication (Walker et al., 2006b). Collaborative Learning features discursive interaction among the parties; participatory communication that features both dialogue and deliberation (Daniels and Cheng, 2004; Walker, 2004, 2007).

Throughout the now 27 years we have guided Collaborative Learning projects, followed Collaborative Learning principles, and enacted Collaborative Learning tools and techniques, we have learned a lot along the way. In doing so, we have at times compared our experiences and lessons learned with the best practices associated with environmental conflict resolution.
The next section of this essay addresses the best practices phenomenon. It does so by discussing the best practices movement generally and best practices associated with environmental conflict management and collaborative decision-making.

\section{BEST PRACTICES}

Environmental conflict management (ECM) scholars typically identify the Storm King Mountain dispute in New York during the 1960s (with a mediated settlement in 1980) and the Snoqualmie River Valley (Washington) conflict in the 1970s as the first cases of environmental conflict resolution in the United States. Both cases ultimately involved mediation to settle the disputes (Morrill and Owen-Smith, 2001).

As the environmental conflict management field evolved, efforts to identify "best practices" in ECM emerged, particularly related to collaboration (collaborative public participation, planning, and decision-making). Most notable was work convened in the mid-1990s by the Environmental/Public Disputes Sector of the Society of Professionals in Dispute Resolution (SPIDR) and the Consortium on Negotiation and Conflict Resolution (CNCR) with support from the William and Flora Hewlett Foundation. The best practices project featured a "critical issues" team that produced a report: Best Practices for Government Agencies: Guidelines for Using Collaborative Agreement-Seeking Processes. That report endures, available today on the website of the Association for Conflict Resolution or ACR (SPIDR evolved into ACR in 2001). The introduction to this report states:

The Committee responsible for the work was comprised of experienced dispute resolution practitioners, government program managers and university researchers. This report focuses on best practices for government agencies and other users in the United States and Canada, reflecting the membership of the SPIDR Environmental/Public Disputes Sector. While potentially applicable to other countries, the recommendations will likely need to be tailored to the political frameworks, institutions and cultural norms in those societies. (Association for Conflict Resolution, SPIDR Documents, 1997)

Focusing on best practices is not unique to the environmental conflict management field; many professions have embraced standards and guidance in the form of best practices. The counseling profession "has increasingly embraced a medicalized vision of counseling processes. The latest manifestation of this vision is the best practices (BP) movement" (Hansen, 2011, p. 154). Best practices have also been identified in the human resources management (HRM) arena. Best practices associated with HRM include communicating employeremployee expectations early, providing feedback frequently, and embracing technology (Casselbury, 2018). In the field of K-12 education, Hargraves and Fullan define "best practices" as "existing practices that already possess a high level of widelyagreed effectiveness" (Hargraves and Fullan, 2012, cited in Alber, 2015). 
Perhaps no profession is more replete with "best practices" than the legal field. In a New York University Law Review essay, Zaring (2006) determines government agencies increasingly turn to "best practices" when developing and implementing regulations. He notes that "the term 'best practices' appeared 300 times in the 2004 Federal Register, up from three appearances in 1980" (2006, p. 297). Other examples: Best practices have been identified in construction law (DeVries, 2018), forest law (FAO, 2005), advertising law (Dunn, 2015), family law (Family Law Council, 2010)—no doubt this list could continue into other legal sectors.

The field in which "best practice" is most closely related to environmental conflict management work is alternative dispute resolution (ADR). As highlighted in ADR Times, the alternative dispute resolution field includes negotiation, mediation, arbitration, and diplomacy (ADR Times). Depending on the source consulted, ADR could include fact-finding, negotiated rule-making, facilitation, dialogue, and any form of informal problem-solving. Simply put, ADR can refer to any process to settle a dispute without litigation (Legal Information Institute, 2017).

Within the ADR field, the practice of mediation is associated with considerable "best practice" efforts. As examples: The International Institute for Conflict Prevention and Resolution released earlier this year the Mediation Best Practices Guide for In-House Counsel: Make Mediation Work for You via its website (CPR, 2018). The Utah Judicial Council published the Utah Mediation Best Practice Guide in 2016 (Utah Judicial Council ADR Committee, 2016). A "best practices" content search on Mediate.com (www.mediate.com), arguably the most comprehensive website in the field, generates dozens of articles that relate a variety of mediator competencies (e.g., listening, empathy, framing) with best practices.

\section{BEST PRACTICES FOR COLLABORATION IN ENVIRONMENTAL CONFLICT MANAGEMENT AND DECISION-MAKING}

Efforts to identify best practices in the environmental conflict management field may not be as prolific as activity in other fields (e.g., the legal/regulatory arena), but some significant work has been done. A review of environmental and public policy dispute resolution firms and organizations reveal investments in "best practices." Examples include the Meridian Institute's Tropical Forest Alliance 2019 project which includes identifying and sharing "best practices for tropical forest and ecosystem conservation" (Meridian Institute, 2019); a CDR Associates' project designed to assess "best practices in social performance and community engagement in unconventional energy development" (CDR Associates, 2016); the Consensus Building Institute's course on advanced land use dispute resolution (CBI, 2012), and University Network for Collaborative Governance and National Policy Consensus Center documents on collaborative competencies and collaborative activities (Kitchen Table Democracy, 2015). These and similar organizations, while referring to best practices, have not developed the "best practice" concept fully.

Three organizations have done so; developing comprehensive sets of best practices related to environmental conflict management and decision-making. The topics covered represent well the best practice efforts and ideas from organizations referenced above and similar organizations. These sets of best practices offer a good basis for comparison with "lessons learned" from almost three decades of Collaborative Learning field work. We have selected these best practice sets because they are comprehensive and they emanate from different sectors of the environmental policy/natural resource management arena.

The SPIDR/CNCR best practices project referred to earlier presents a set of recommendations drawn from both ECR research and practice. After discussing concerns and problems related to stakeholder engagement and collaboration, the SPIDR/CNCR Critical Issues Committee offered eight recommendations, noting that the "recommendations are directed primarily toward federal, state, provincial, and territorial government officials to help ensure successful use of collaborative processes for decision making...The recommendations... propose a set of best practices for use of collaborative decision-making processes." (Association for Conflict Resolution, SPIDR Documents, 1997; see also Bellman and Podziba, 2014).

1. An agency should first consider whether a collaborative agreement-seeking approach is appropriate.

2. Stakeholders should be supportive of the process and willing and able to participate.

3. Agency leaders should support the process and ensure sufficient resources to convene the process.

4. An assessment should precede a collaborative agreementseeking process.

5. Ground rules should be mutually agreed upon by all participants, and not established solely by the sponsoring agency.

6. The sponsoring agency should ensure the facilitator's neutrality and accountability to all participants.

7. The agency and participants should plan for implementation of the agreement from the beginning of the process.

8. Policies governing these processes should not be overly prescriptive. (Association for Conflict Resolution, SPIDR Documents, 1997)

Sustainable Northwest, a Portland, Oregon-based NGO, has also addressed best practices. Sustainable Northwest's projects integrate human and natural systems (community, ecology, economy) to solve environmental problems. The organization has been a pioneer in collaborative problem-solving and community involvement in natural resource management (Sustainable Northwest). As part of its work on collaboration and forest management, Sustainable Northwest has produced the Stewardship Contracting and Collaboration Best Practices Guidebook. The guidebook addresses best practices in terms of:

1. How to collaborate

2. Creating a collaborative group 
3. Recruiting participants

4. Holding effective meetings

5. Creating a mission statement

6. Defining participant roles and responsibilities

7. Establishing ground rules and group protocols

8. Making decisions

9. Providing facilitation

10. Learning about issues

11. Developing procedures for changes in group membership

12. Understanding relevant legislation and regulation, such as the Federal

13. Advisory Committee Act (FACA)

14. Managing communication

15. Conducting both media and political relations (Boetsch, 2008).

The National Estuarine Research Reserve Association (NERRA, 2018) is a national nonprofit organization established in 1987 to advance the work of the National Estuarine Reserves system. Reserves, regional "friends" groups, and partners rely on NERRA to help enhance successful programs and enable the Reserves to effectively address growing challenges to the nation's estuaries, coasts, and communities (NERRA, 2018).

NERRA provides resources to support stakeholder engagement and collaborative planning and decision-making. One resource is the Collaborative Project Toolkit. In introducing the Toolkit, the NERRA website states:

Collaboration may be key to understanding and managing coastal and estuarine environments, but no one ever said it would be easy. Reserve-based projects routinely involve a mix of scientists from different disciplines, public officials and agencies, partners from nongovernmental organizations, educators, students, and citizens. Bringing such diverse partners and stakeholders together for a common purpose can be challenging, time consuming, and resource intensive.

This toolkit was created to help... The content and design of this toolkit is based on the cumulative experience of grantfunded research projects from across the National Estuarine Research Reserve System from 2009 to the present. These projects involved hundreds of partners from the public and private sectors, including academic experts from the fields of collaborative science, seasoned educators, and outreach and training veterans (NERRA, 2018).

The Toolkit includes two sections: Case Studies and Best Practices. The Best Practices Section features one to two-page documents, each labeled as "best practices," about the following set of topics, organized into four sections:

\section{Planning}

- Generating cross sector ideas

- Building a strong team

- Choosing your collaborative approach

- Developing a budget

\section{Doing}

- Project management

- Using collaboration software
- Formative evaluation

- Dealing with change

- Managing conflict

- Engaging stakeholders

- Advisory boards

- Effective meetings

- Gearing up

- Communicating with stakeholders

\section{Wrapping up}

- Leveraging the reserve system to share your work

- Summative evaluation

- Project retrospective

- Keeping the momentum going with partners and stakeholders (NERRA, 2018)

As an aid to the comparative discussion (best practices and CL lessons), the best practice statements and topics from SPIDR/CNCR (SPIDR), Sustainable Northwest (SN), and NERRA have been condensed and organized in a Best Practices Table (Table 1). The topics highlighted in the Table are those that appear significantly in at least two of the three best practices documents.

These nine best practices topic areas reflect a collective emphasis of SPIDR/CNCR, Sustainable Northwest, and NERRA. As the lists presented reveal, some topics appear only once (e.g., SN's "learning about issues"). A topic appearing only once does not minimize its importance; these best practices documents are prepared in different contexts and intended for particular audiences.

\section{COLLABORATIVE LEARNING AND BEST PRACTICES}

Our Collaborative Learning field experiences, whether as consultants/researchers or as members of the National Collaboration Cadre, generally affirm the sets of best practices developed by SPIDR/CNCR, Sustainable Northwest, and NERRA. This explanation unfolds in the conceptual areas highlighted.

\section{Assessment}

When we first developed CL, we recognized that the $\mathrm{CL}$ approach we took would depend on our understanding of the situation. Consequently, we identified "situation assessment" as the first stage of a CL project (Daniels and Walker, 2001). As consultants/researchers, we needed to conduct an assessment, and in doing so, we realized that we needed to incorporate "situation assessment" into the workshops we designed to citizen engagement. We have developed and guided systems thinking activities, such as situation maps and generation walls, into our CL and Cadre workshops. $\mathrm{CL}$ assessment work includes tools for assessing "collaborative potential." If the need for collaboration is high while the potential is low, we work with agencies and stakeholders to identify ways to improve the collaborative potential (Walker et al., 2015). We have also drawn on our CL experience to 
TABLE 1 | Recommended best practices.

\begin{tabular}{|c|c|}
\hline Best practice topic & Summary \\
\hline Planning and assessment & $\begin{array}{l}\text { SPIDR states that the situation should be assessed before proceeding with a collaborative project and appropriateness should } \\
\text { be determined. NERRA planning includes some assessment work as part of choosing a collaborative approach. }\end{array}$ \\
\hline Stakeholder participation & $\begin{array}{l}\text { SPIDR recommends seeking stakeholder support. SN offers advice on how to create a collaborative group, recruit participants, } \\
\text { and handle changes in group membership. NERRA provides "best practice" information on engaging stakeholders. }\end{array}$ \\
\hline Leadership involvement and support & $\begin{array}{l}\text { NERRA presents best practices material about how to include advisory boards or committees, such as a technical committee; } \\
\text { and the important role of a strong project team. SPIDR notes that agency leaders need to support the collaborative process. SN } \\
\text { states that projects like stewardship contracting are initiated by agency administrators, such as a Forest Service District Ranger. }\end{array}$ \\
\hline Effective meetings and ground rules & $\begin{array}{l}\text { NERRA and SN offer advice about effective meetings. SPIDR includes in an appendix about ground rules some comments on } \\
\text { the conduct of meetings. Both SPIDR's and SN's best practices include establishing ground rules. NERRA's two pages of advice } \\
\text { about effective meetings contains a statement about ground rules. }\end{array}$ \\
\hline Resources & $\begin{array}{l}\text { SPIDR urges agencies to provide sufficient resources, such as staff time and funding. NERRA highlights preparing a budget and } \\
\text { using software. }\end{array}$ \\
\hline Facilitation & $\begin{array}{l}\text { Both SPIDR and SN include facilitation in their best practices guidelines. An appendix in the SPIDR documents provides a list of } \\
\text { "do's and don'ts" for facilitators and mediators. SN provides advice on the need for a facilitator and who might serve in that role. } \\
\text { NERRA refers to facilitation in its effective meetings material. }\end{array}$ \\
\hline Communication & $\begin{array}{l}\text { NERRA provides guidance on communicating with stakeholders, including actions for "gearing up" (conducting outreach). SN } \\
\text { includes discussion of communicating the media and political actors. }\end{array}$ \\
\hline Decision-making & SN features decision making as one of its best practices topics. SPIDR refers to decision rules within its material on ground rules. \\
\hline Implementation and evaluation & $\begin{array}{l}\text { NERRA recommends a form of stock-taking; collaborative project participants evaluating the project mid-course and making } \\
\text { corrections. It also proposes a project summary evaluation. SPIDR advises collaborative groups to discuss implementation of an } \\
\text { agreement early in the process. It urges parties to set out clear steps and stages for implementation and clarify tasks, resources, } \\
\text { responsibilities, and deadlines. }\end{array}$ \\
\hline
\end{tabular}

development frameworks for assessment, such as the Progress Triangle (Daniels and Walker, 2001), the Unifying Negotiation Framework (Daniels et al., 2012), and Collaborative Alignment (Walker et al., 2018).

Some assessment work has involved one-on-one conversations (e.g., Walker et al., 2006b); Cadre projects have typically included listening sessions or community conversations in the first phase of a project, much like semi-structured focus groups (Walker et al., 2019). We have learned that these conversations need to occur both within organizations (e.g., involving National Forest personnel) and the communities.

\section{Stakeholder Participation}

The three sources of best practices that we feature offer sound advice on stakeholder participation; this is central to an appropriate collaborative project. Our CL experience confirms this, and we include in CL principles access and inclusion. We have encouraged agencies and organizations to be as inclusive as possible and invite the parties they view as critics. In recent years we have advised project developers (i.e., agencies) to use technology to increase participation. For example, Cadre projects often include the use of a collaborative mapping tool (Aran and Reed, 2015).

\section{Leadership}

Although it addresses leadership, much of the best practices literature does not do so in depth. When we wrote the book, Working through Environmental Conflict: The Collaborative Learning Approach (Daniels and Walker, 2001), we overlooked leadership and its importance to a productive collaborative effort. In fact, a Forest Service colleague, after reading the book, commented that while the book covered many aspects of collaboration, leadership was a missing piece.

Our field experience confirms our colleague's view. Collaborative efforts need to address leadership in the agencies, the stakeholder organizations, and communities. Unifying, collaborative leadership matters (Walker and Senecah, 2011; Walker and Daniels, 2012). The SPIDR report recommends that agency leaders support a collaborative process. We would go further. Agency managers - to be leaders-need to understand, support, and invest in the collaborative work. They need to demonstrate their commitment to collaboration. This is often confounded by turnover in agency management positions (Walker and Daniels, 2012).

\section{Meetings and Ground Rules}

Asserting that good meeting procedures and ground rules are essential for multi-stakeholder collaboration may be stating the obvious. Our CL and Cadre experiences are consistent with what the SPIDR, SN, and NERRA reports advise. Assessment informs meeting design; good ground rules can be drawn from the mediation and facilitation literature and experience. Meeting design challenges we have faced include when and to hold meetings and for how long. Some CL and Cadre workshops are designed for an entire day, often on a Saturday so that people don't have to miss work. Meetings are typically held at a neutral site (as opposed to a government building), such as a community center or school. Evening meetings are scheduled so people have a reasonable drive home. Design decisions are collaborative; drawing on the 
ideas, preferences, and experiences of community members and agency staff.

\section{Resources}

Much of the best practices literature, in both ECR and other fields, recognizes the importance of resources. Certainly, funding and information resources are important, but time may be the most critical. Collaborative work requires time. A convening organization's personnel need time to prepare for and participate in collaborative projects. Stakeholders/citizens need similar time as well. Agency staff and some stakeholder personnel may participate as part of their jobs; getting paid to collaborate. Citizens, though, volunteer their time, something conveners need to honor and respect.

\section{Facilitation}

Just as the SPDR and SN recommendations feature facilitation, we consider facilitation an essential component of a collaborative process. Both CL and Cadre work employ co-facilitation; teams of 2-4 people. Ideally, the facilitation team is diverse, with women and men with varied backgrounds, professions, experiences, and language competencies. Facilitators need to skilled conflict and process managers and should have a working knowledge of the context and issues being addressed.

\section{Communication}

NERRA and SN draw attention to communication, as does much of the best practices literature. From our field experience, we contend that the topic of communication needs more attention than it typically gets. For example, in many of our Cadre projects we work with agencies and stakeholders to develop communication and participation plans alongside collaborative action plans (Walker et al., 2019). CL work considers communication as dynamic and draws attention to how messages are designed, what modes are appropriate (e.g., face-to-face, social media, email), and how messages will be interpreted-what meanings will be constructed (Daniels and Walker, 2001; Walker et al., 2015). Consequently, our CL efforts often include communication "coaching."

\section{Decision-Making}

Only the Sustainable Northwest best practices set (tied to stewardship contracting) identifies decision-making as a major area. Our CL projects and Cadre work focus significantly on how decisions are made, by the stakeholders as well as the agencies. We coach agency leadership to clarify to their own staff and stakeholders the nature of the decision space (what can be influenced or negotiated) as well as any sideboards. We have found that stakeholders want to know what role they may play in the planning and decision-making process and in what ways their ideas can influence decisions.

In our collaborative work we are responsive to decision authority and any procedural concerns, such as compliance with the Federal Advisory Committee Act (FACA). FACA is addressed as part of Sustainable Northwest's best practices.

\section{Implementation and Evaluation}

Implementing the results of a collaborative effort and evaluating both process and outcome are essential practices. Stakeholders expect decisions to be implemented, and collaboration should include shared implementation (Gray, 1989). CL's attention to both these areas is consistent with NERRA and SPIDR best practices. Evaluation needs to be both during and at the end of a collaborative project. Implementation activities should be monitored with changes made appropriately (i.e., mid-course and end-course corrections).

\section{COLLABORATIVE LEARNING AND BEST PRACTICES-ADDITIONAL AREAS TO CONSIDER}

The SPIDR, SN, and NERRA best practice guides present wellgrounded recommendations on how to work on challenging issues and make good decisions through collaboration. Our CL fieldwork confirms these organizations' best practices and also reveals areas their guides do not address substantially. We present these additional areas, not as criticism, but to share what we have learned in the field.

\section{Decision Space}

When we get a call or email about a potential project, one of the first things we discuss with the decision authority (e.g., a government agency) is the nature of the decision space. The more issues that are "on the table" for negotiation and influence the greater the collaborative potential. Stakeholders want to know what issues are open for discussion. For example, one of our earliest CL field projects involved a national recreation area managed by a National Forest (the USDA-Forest Service). As we designed and facilitated community workshops about this recreation area, we asked National Forest managers to clarify what was "within" and "outside" the decision space. Recreation area curfews and invasive species eradication were within the decision space, while threatened and endangered species were not (Daniels and Walker, 1996).

\section{Follow Up and Follow Through}

The ECR best practices literature addresses implementation. We how important stakeholder view this practice. They want to see decision authorities follow through on their commitments and follow up on stakeholder participation. Stakeholders have told us repeatedly that they want evidence that someone paid attention to their ideas. When decision makers explain how they attended to stakeholder contributions and demonstrate that some stakeholder ideas impacted the decision, the decision makers provide transparency and validation.

\section{Purpose and Principles}

In its set of best practices, Sustainable Northwest calls for developing a mission statement. A foundation for collaboration is strengthened through the development of a statement of purpose, a mission statement, a shared vision, goals/objectives, and/or a set of principles. The relatively new Collaborative Alignment framework begins with purpose (Walker et al., 2018). 
Along with purpose come principles and commitment. Before working on the substantive issues of a collaborative project, participants can devote time to proposing, discussing, and deciding on a set of guiding principles. Reaching consensus on procedure (what $\mathrm{SN}$ refers to as group protocols) is often easier than doing so on matters of substance, and procedural agreements demonstrate commitment and build trust.

\section{Respecting Expectations}

Best practices guidelines should recognize that collaborative processes change and raise expectations both within organizations and among stakeholders. If a collaborative project is successful, both of decision support and improved relationships, parties may prefer and expect collaboration on subsequent projects. Such expectations may carry over to related areas, such as improved communication and honoring agreements, even when leadership changes. For example, we worked with a National Forest for almost 3 years, directing stakeholder engagement activities related to forest planning. During that period, the forest planner, planning staff officer, and forest supervisor all left for other jobs. Their replacements did not pursue prior commitments and the staff changes were not communicated well-externally. As consultants/researchers, we received calls from stakeholders asking us what was going on. When we returned to work with the National Forest we had to rebuild the collaborative effort, and we did so in the face of public skepticism.

\section{Training/Capacity Building}

As part of one of our first CL projects, we designed and facilitated a series of community workshops tied to a forest planning effort. They were well-attended, and citizens generated a numerous of ideas that the Forest Staff found helpful. We noticed during the workshops, though, that most of the National Forest employees at the workshops were standing at the back of the room, often with arms crossed or talking with fellow staff. We realized that while the Forest leadership (forest supervisor and district rangers) understood and endorsed our Collaborative Learning approach, general Forest personnel (including key resource specialists) did not. We had not considered the important of staff training, and we learned that lesson well. CL and Cadre projects since have included basic (and in some cases advanced) training in Collaborative Learning and collaborative processes generally (see Daniels and Walker, 2001 for an example).

\section{Knowledge and Information}

Best practices should extend to how information is managed and accessed. They should also consider forms of knowledge and how people learn. For example, a Cadre project that included citizen "listening sessions" asked participants about their information and communication needs and concerns. They expressed preferences for education, communication, and respect for the regions cultural traditions (Walker et al., 2019).

As part of CL projects, we have often asked a local person (non-agency) to be a presenter at community workshops/meetings. For example, on during a fire recovery planning project with a National Forest, we met a local logger who was also a photographer. He was on the front lines of the fire, working alongside Forrest Service firefighters. His forest knowledge and photos were impressive, and we asked him to speak at our fire recovery public workshops. Some Forest Service employees raised doubts and concerns, but later acknowledged that he was one of the best presenters.

\section{Contingency Planning}

Although this potential best practice topic may seem less significant than others, contingency planning has been an important part of our Collaborative Learning field projects. With each project and for each workshop we ask agency personnel and community leaders what "surprises" might occur, both in terms of behavior and people. We do not expect these surprise behaviors, but we want to have a plan if they occur.

For example, as we prepared for an evening workshop as part of a National Forest Planning effort, we learned that a rumor was spreading through town that the National Forest was going to close the forest to snowmobiles. Our meeting was scheduled for the same week and town in which a national snowmobile competition was taking place. Consequently, we thought that some snowmobilers might come to the workshop with an agenda different than the one we had prepared. Consequently, we prepared a side room with separate materials to diffuse a potentially difficult situation and advised key Forest personnel to be ready to participate in the side room discussion. About a dozen out-of-town snowmobilers did come to the workshop and met with Key the designated Forest staff. They were satisfied with that conversation and joined the full workshop (of about 100 people). In planning for contingencies we do not expect challenging behavior; we want to be ready for it if it occurs (e.g., open microphone time, Daniels and Walker, 2001).

\section{Organizational Change}

Just as we overlooked leadership when we wrote the 2001 book on Collaborative Learning, we have recognized that we should have addressed organizational change. For some agency personnel, interest group advocates (e.g., conservation, industry), and citizen/stakeholders, collaboration may seem risky or accommodating. Changing their views and commitments may require an organizational "paradigm shift," where environmental and natural resources management agencies such as the Forest Service, the Bureau of Land Management, and the Fish and Wildlife Service and state agency equivalents pay collaborative planning and engagement a top procedural priority. Doing so would be akin to transforming from a technical management or regulatory identity to a learning organization (Senge, 1990). A learning organization rewards innovation and see value in its members learning from and with one another (Senge, 1990).

\section{CONCLUSION}

In considering three prominent best practice guides, we identified 9 best practice topics that emerged from our review. To that list we have drawn on our field experience and have added eight. Together, the 17 best practice areas cover many aspects of collaborative work. 
As we feature these 16 areas, we acknowledge that: (1) other areas may deserve equal attention, such as building and maintaining relationships, clarifying a shared purpose, employing mutual gains negotiation; and attending to salient cultural factors; (2) we have selected only 3 best practice guides from specific arenas (a professional organization, a nonprofit organization, and a research organization); and (3) we have seemingly embraced the concept of the "best practice" without critique.

First, there are certainly other areas to consider when doing collaborative work and we do not want to minimize the importance of any factor in a specific situation. For example, when working on a project that involves underrepresented or marginalized communities, culture and language issues gain prominence. When pursuing a project with communities that have lost faith in government institutions, activities to establish a reasonable degree of trust may be needed before the substantive issues are tackled.

Second, there are other documents to consider from a variety of organizations (such as government, non-government, community-based) if the goal is a more universal natural resources/environmental policy decision-making "best practice" guide. Examples include from government, U.S. Army Corps of Engineers work about collaboration in integrated water resource management (Civil Works Directorate, 2014); from the NGO forest management community, the National Forest Foundation, whose "collaboration resources" topics cover many of the best practice areas features in this essay (National Forest Foundation, 2019); from the NGO waste management community, the Composting Collaborative, a national-wide multi-stakeholder organization with the mission to "accelerate composting access and infrastructure to improve soil health and divert compostables from landfill" (Composting Collaborative, 2018); and from the NGO conservation community, the American Lands Alliance work on best practices in collaboration (American Lands Alliance, 2007); and from information hubs, such as the Red Lodge Clearinghouse, a repository of collaboration resources, such as cases studies and lessons learned (http://www.rlch.org/).

Third, one can question to validity (and generalizability) of any list of best practices. Certainly the "best practice" literature is built on a foundation of research and/or experience. The SPIDR/CNCR Critical Issues Committee, for example, "was comprised of experienced dispute resolution practitioners, government program managers and university researchers" (SPIDR/CNCR). Both the Sustainable Northwest and NERRA guides were grounded in numerous case studies, projects, and the efforts community-based groups (e.g., forest collaboratives). Our ideas about effective collaboration reflects our field experience, research, and reading of relevant literature.

In our work, though, we have not labeled our ideas about good collaboration as "best practices." Collaboration is contextdependent, and we have tailored our CL application and tools to each specific situation. Rather than best practices, we prefer to think of the work of the SPIDR/CNCR Critical Issues Committee, Sustainable Northwest's best practices about collaboration and stewardship contracting, and the National Estuarine Research Reserve Association's Collaborative
Tool Kit as providing guidelines for constructive and appropriate collaboration.

Still, there is value in learning from and with others in the environmental and natural resource policy decision-making field. While collaboration varies according to both scale and scope, field experience and academic research can generate knowledge about collaboration that can guide multi-stakeholder efforts.

Two recent books illustrate well the importance of learning both from field experience and academic research and the importance of integrating the two. Clarke and Peterson's Environmental Conflict Management (Clarke and Peterson, 2016), proves well-grounded (both in theory and research) and comprehensive discussion of environmental conflict. The book includes numerous examples of how environmental communication and collaboration concepts relate to real world events. For example, to illustrate the importance of cultural considerations, Clarke and Peterson feature the sewage management problem in Cyprus (Clarke and Peterson, 2016, p. 17-18).

Clarke and Peterson, both communication scholars, assert that conflict (and therefore environmental conflict) is "a communication process" and that "social interaction is fundamental to conflict" (2016, p. 2). In one of the book's most important chapters (on communication capacity building), Clarke and Peterson present a set of competencies that could be re-cast as "communication best practices" in environmental conflict management.

By comparison, Margerum and Robinson's edited volume, The Challenges of Collaboration in Environmental Governance: Barriers and Responses (2016), features authors primarily from the fields of political science, public policy, and public administration. While Clarke and Peterson's work focuses much attention on meso-scale (group, organizational) and micro-scale (individual) factors such as communication competencies, the essays in Margerum and Robinson's book focus on the macro (institutional, bureaucratic) and meso scales. Margerum and Robinson assert in the book's introduction that "the collaborative approach to planning, management, and governance has a deep history in political science, public administration, planning, sociology, resilience theory, and natural resource management." They contend that "the concept has evolved from a range of concepts and ideas related to public participation, conflict resolution, democratic governance and increasingly complex problems that belied traditional solutions" (p. 3).

The essays in The Challenges of Environmental Governance cover a variety of issues, such as theoretical perspectives of collaboration, network analysis, the role of science, climate change adaptation, transformational learning, indigenous partnerships, politics, and power. Three of the chapters refer to "best practices" as part of discussion about how the collaboration theories and contexts have evolved.

Taken together, Environmental Conflict Management and The Challenges of Environmental Governance could serve as a good starting point for developed a new and contemporary set of "best practices" for work in the environmental and natural resource policy a arenas. From there, an analyst could consider numerous publications (such as those cited in this essay; perhaps a kind 
of meta-analysis) from a variety of disciplines to construct a generalized view of best practices. Doing so is well-beyond the scope and purpose of this essay.

Writing over a decade ago, collaborative governance, and public administration scholars Bingham et al. wrote that "Citizens can and must play an important role in public policy and decision making." The scholars emphasized that "Public administration practitioners and scholars must reengage the public in governance and recognize the special duty they have to citizens" (Bingham et al., 2005, p. 555). But how should this be done? This essay has focused on three sets of best practices in environmental and natural resource policy decision making and compared those practices with insights from Collaborative Learning fieldwork. This discussion, though, does not imply that collaboration should be used in every management decision-making process. Rather, best practices,

\section{REFERENCES}

Alber, R. (2015). Defining "Best Practice" in Teaching. Edutopia. Available online at: https://www.edutopia.org/blog/defining-best-practice-teaching-rebecca-alber American Lands Alliance (2007). Collaboration Best Practices for the Conservation Community. Available online at: https://www.fs.fed.us/emc/nepa/ecr2008/ sessions/materials/13/Final\%20Collaboration\%20Guidelines\%203-07.pdf

Amy, D. (1987). The Politics of Environmental Mediation. New York, NY: Columbia University Press.

Aran, E., and Reed, P. (2015). Talking Points Collaborative Mapping: Forest Service Public Participation GIS Application. Available online at: http://proceedings. esri.com/library/userconf/proc15/papers/890_503.pdf

Association for Conflict Resolution, SPIDR Documents (1997). Best Practices for Government Agencies: Guidelines for Using Collaborative Agreement-Seeking Processes. Report and Recommendations of the SPIDR Environment/Public Disputes Sector Critical Issues Committee., Adopted by the SPIDR Board January 1997. Copyright 1997 SPIDR (now merged with AFM and CREnet to form the Association for Conflict Resolution). Available online at: https://cdn.ymaws.com/acrnet.org/resource/resmgr/docs/Best_Practices_for_ Governmen.pdf

Bellman, H. S., and Podziba, S. L. (2014). Public policy mediation: best practices for a sustainable world. Dispute Resol. Magaz. 20, 22-26.

Bingham, G. (1986). Resolving Environmental Disputes: A Decade of Experience. Washington DC: The Conservation Foundation.

Bingham, L. B., Nabatchi, T., and O'Leary, R. (2005). The new governance: practices and processes for stakeholder and citizen participation in the work of government. Public Admin. Rev. 65, 547-558. doi: 10.1111/j.1540-6210.2005.00482.x

Blatner, K. A., Carroll, M.S., Daniels, S. E., Walker, G. B. (2001). Evaluating the application of collaborative learning to the Wenatchee fire recovery planning effort. Environ. Impact Assess. Rev. 21, 241-270. doi: 10.1016/S0195-9255(00)00080-9

Boetsch, A. (2008). Stewardship Contracting and Collaboration: Best Practices Guidebook. Portland, OR: Sustainable Northwest.

Casselbury, K. (2018). The Best Practices for Human Resources. Chron (Houston Chronicle on-line). Available online at: https://smallbusiness.chron.com/ practices-human-resources-15953.html

CBI (2012). Advanced Land Use Dispute Resolution. Available online at: https:// www.cbi.org/tool/advanced-land-use-dispute-resolution/

CDR Associates (2016). Alfred P. Sloan and Cynthia and George Mitchell Foundation Fund CDR Assessment of Industry Best Practices. Available online at: http://cdrassociates.org/industry-best-practices/

Checkland, P., and Scholes, J. (1990). Soft Systems Methodology in Action. New York, NY: John Wiley and Sons. guidelines, lessons learned, or insights should guide decision makers and stakeholders to determine if a collaborative approach is appropriate, and if so, what factors to address (Walker et al., 2015). "Decision makers are often able to choose the extent to which a DMP [decision-making process] is going to be participatory or collaborative," Newig et al. (2018) contend, adding: hat "collaboration and participation, then, are a choice rather than a necessity" ... governance modes are "strategic interventions that can help achieve certain goals" (2018, p. 270). Decision makers choose to collaborate. So, too, do stakeholders. Considering best practices can be useful to that decision.

\section{AUTHOR CONTRIBUTIONS}

All authors listed have made a substantial, direct and intellectual contribution to the work, and approved it for publication.

Civil Works Directorate (2014). Building Strong Collaborative Relationships for a Sustainable Water Resources Future: Understanding Integrated Water Resources Management (IWRM). Washington, DC: US Army Corps of Engineers.

Clarke, T., and Peterson, T.L. (2016). Environmental Conflict Management. Los Angeles, CA: Sage.

Composting Collaborative (2018). About. Available online at: https://www. compostingcollaborative.org/about/

Cortner, H. J., and Moote, M. A. (1998). The Politics of Ecosystem Management. Washington, DC: Island Press.

CPR (2018). CPR Releases New Mediation Best Practices Guide for In-House Counsel Make Mediation Work for You. The International Institute for Conflict Prevention and Resolution. Available online at: https://www.cpradr.org/newspublications/press-releases/2018-03-08-cpr-releases-new-mediation-bestpractices-guide-for-in-house-counsel

Daniels, S. E., and Cheng, A. S. (2004). "Collaborative resource management: discourse-based approaches and the evolution of TechnoReg," in Society and Natural Resources: A Summary of Knowledge, eds M. L Manfredo, J. J. Vaske, B. L. Bruyere, D. R. Field, and P. J Brown (Jefferson, MO: Modern Litho), 127-136.

Daniels, S. E., and Walker, G. B. (1996). Collaborative learning: improving public deliberation in ecosystem-based management. Environ. Impact Assess. Rev. 16, 71-102.

Daniels, S. E., and Walker, G. B. (2001). Working Through Environmental Conflict: The Collaborative Learning Approach. Westport, CT: Praeger.

Daniels, S. E., and Walker, G. B. (2012). Lessons from the trenches: twenty years of applying systems thinking to environmental conflict. Syst. Res. Behav. Sci. 29, 104-115. doi: 10.1002/sres. 2100

Daniels, S. E., Walker, G. B., Emborg, J. (2012). The unifying negotiation framework: a model of policy discourse. Conflict Resol. Q. 30, 3-31. doi: $10.1002 /$ crq. 21045

DeVries, M. (2018). Best Practices Construction Law - blog. https://www. bestpracticesconstructionlaw.com/

Dukes, E. F. (1996). Resolving Public Conflict: Transforming Community and Governance. Manchester, UK: Manchester University Press.

Dunn, H. (2015). Five Best Practices in Advertising Law. Marketing News. American Marketing Association. Available online at: https:/www.ama.org/ publications/MarketingNews/Pages/five-best-practices-in-advertising-law. aspx

Emerson, K., and Nabatchi, T. (2015). Collaborative Governance Regimes. Washington, DC: Georgetown University Press.

Family Law Council (2010). Best Practice Guidelines for Lawyers Doing Family Law Work, 2nd edn. Canberra, ACT: Family Law Council and Family Law Section of the Law Council of Australia, Commonwealth of Australia.

FAO (2005). Best Practices for Improving Law Compliance in the Forestry Sector. FAO Forestry Paper 145. Rome: Food and Agriculture Organization of the United Nations International Tropical Timber Organization. 
Fisher, R., and Ury, W. (1991). Getting to Yes: Negotiating Agreement without Giving In, 2nd Edn. New York, NY: Basic Books.

Gray, B. (1989). Collaborating: Finding Common Ground for Multiparty Problems. San Francisco, CA: Jossey-Bass.

Hansen, J. T. (2011). Is the best practices movement consistent with the values of the counseling profession? Counsel. Values 50, 154-160. doi: 10.1002/j.2161-007X.2006.tb00051.x

Hargraves, A., and Fullan, M. (2012). Professional Capital: Transforming Teaching in Every School. New York, NY: Teachers College Press.

Hocker, J. L., and Wilmot, W. W. (2017). Interpersonal Conflict, 10th Edn. New York, NY: McGaw-Hill.

Janis, I. L. (1982). Groupthink: Psychological Studies of Policy Decisions and Fiascoes, 2nd Edn. Boston, MA: Wadsworth.

Kitchen Table Democracy (2015). Tools and Resources. Available online at: http:// www.kitchentable.org/tools

Kolb, D. (2015). Experiential Learning: Experience as the Source of Learning and Development, 2nd Edn. Upper Saddle River, NJ: Pearson Education.

Koontz, T. M., Steelman, T. A., Carmin, J., Smith Korfmacher, K., Moseley, C., Thomas, C. W. (2004). Collaborative Environmental Management: What Role for Government? Washington, DC: Resources for the Future Press.

Legal Information Institute (2017). Alternative Dispute Resolution. Ithaca, NY: Cornell Law School. Available online at: https://www.law.cornell.edu/wex/ alternative_dispute_resolution

Lewicki, R. J., Saunders, D. M., and Barry, B. (2015). Negotiation, 7th Edn. New York, NY: McGraw-Hill.

Margerum, R. D., and Robinson, C. J., (eds.) (2016). The Challenges of Collaboration in Environmental Governance: Barriers and Responses. Northampton, MA: Edward Elgar Publishing.

McKinney, M., and Harmon, W. (2004). The Western Confluence: A Guide to Governing Natural Resources. Washington, DC: Island Press.

Meridian Institute (2019). Tropical Forest Alliance 2019. Available online at: http:// www.merid.org/en/Content/Projects/Tropical_Forest_Alliance_2019.aspx

Moore, C. W. (2014). The Mediation Process: Practical Strategies for Resolving Conflict, 4th Edn. San Francisco, CA: John Wiley.

Morrill, C., and Owen-Smith, J. (2001). "The emergence of environmental conflict resolution subversive stories, institutional change, and the construction of fields," in Organizations, Policy, and the Natural Environment: Institutional and Strategic Perspectives,eds M. Ventresca and A. Hofman (Stanford, CA: Stanford University Press), 90-118.

National Forest Foundation (2019). Collaboration Resources. Available onlne at: https://www.nationalforests.org/collaboration-resources

NERRA (2018). Collaborative Project Toolkit. Wells, ME: National Estuarine Research Reserve Association.

Newig, J., Challies, E., Jager, N. W., Kochskaemper, E. and Adzersen, A (2018). The environmental performance of participatory and collaborative governance: a framework of causal mechanisms. Policy Stud. J. 46, 269-297. doi: $10.1111 / \mathrm{psj} .12209$

Orr, S. K. (2014). Environmental Policymaking and Stakeholder Collaboration: Theory and Practice. Bocas Raton, FL: CRC Press.

Senge, P. (1990). The Fifth Discipline: The Art and Practice of the Learning Organization. New York, NY: Currency.

Susskind, L., and Field, P. (1996). Dealing with an Angry Public: The Mutual Gains Approach to Resolving Disputes. New York, NY: The Free Press.

Susskind, L., Levy, P.F., and Thomas-Larmer, J. (2000). Negotiating Environmental Agreements: How to Avoid Escalating Confrontation, Needless Costs, and Unnecessary Litigation. Washington, DC: Island Press.

Utah Judicial Council ADR Committee (2016). Utah Mediation Best Practice Guide. Available online at: http://www.utcourts.gov/mediation/docs/ MediationBestPracticesGuide-FinalDraft.pdf
Walker G. B., Senecah, S. L., Daniels, S. E. (2007). "Reflections from the road: new and improved concepts, tools, and lessons for community-based collaboration," in Proceedings of the 8th Biennial Conference on Communication and the Environment, eds L. S. Volkening, D. Wolfe, E. Plec, W. Griswold, and K. DeLuca (Athens, GA: University of Georgia Department of Speech Communication), 213-234.

Walker, G.B., Daniels, S.E., Timko, S., Lockwood, C., Hansen, S. (2019). "Listening and learning: stakeholder views of participation and communication in forest planning," in Breaking Boundaries: Innovative Practices of Communication and Public Participation in Environmental Decision Making, eds K. Hunt, G. Walker, and Depoe S (Albany, NY: State University of New York Press).

Walker, G.B., Senecah, S.L., and Daniels, S.E. (2006b). From the forest to the river: citizen views of stakeholder engagement. Hum. Ecol. Rev. 13, 193-202.

Walker, G. B. (2004). "The roadless areas initiative as national policy: is public participation an oxymoron?" in Communication and Public Participation in Environmental Decision Making, eds S. W. Depoe, J. W. Delicath, M-F. Aepli Elsenbeer (Albany, NY: State University of New York Press), 113-136.

Walker, G. B. (2007). Public participation as participatory communication in environmental policy decision-making: from concepts to structured conversations. Environ. Commun. J. Nat. Cult. 1, 99-110. doi: 10.1080/17524030701334342

Walker, G. B., Daniels, S. E. (2012). "The nature and role of agency leadership: Building and sustaining collaboration in natural resource management and environmental policy decision-making," in Environmental Leadership: A Reference Handbook, ed D. Rigling Gallagher (Thousand Oaks, CA: Sage), $147-158$.

Walker, G. B., Daniels, S. E., and Cheng, A. (2006a). "Facilitating dialogue and deliberation in environmental conflict: the use of groups in collaborative learning," in Facilitating Group Communication: Innovations and Applications With Natural Groups, ed L. Frey (Cresskill, NJ: Hampton Press), 205-238.

Walker, G. B., Daniels, S. E., and Emborg, J. (2015). "Public participation in environmental policy decision making: insights from twenty years of collaborative learning fieldwork," in The Routledge Handbook of Environment and Communication, eds A. Hansen and R. Cox (London: Routledge), 111-130.

Walker, G. B., and Senecah, S. L. (2011). "Collaborative governance: integrating institutions, communities, and people," in Community-Based Collaboration: Bridging Socio-Ecological Research and Practice, eds E. F. Dukes, K. E. Firehock, and J. E. Birkhoff (Charlottesville, VA: University of Virginia Press), 111-145.

Walker, G. B., Severson, G., and Daniels, S. E. (2018). "Collaborative Alignment: a framework for community-based collaborative action for adaptation," in Marketplace Presentation at the 12th Conference on Community-Based Adaptation (Lilongwe).

Weber, E. P. (2003). Bringing Society Back In. Cambridge, MA: The MIT Press.

Wilson, K. K., and Morren, G. E. B. (1990). Systems Approaches for Improvement in Agriculture and Resource Management. New York, NY: MacMillan.

Wondolleck, J. M., Yaffee, S. L. (2000). Making Collaboration Work: Lessons From Innovation in Natural Resource Management. Washington, DC: Island Press.

Zaring, D. (2006). Best practices. NYU Law Rev. 81, 294-350.

Conflict of Interest Statement: The authors declare that the research was conducted in the absence of any commercial or financial relationships that could be construed as a potential conflict of interest.

Copyright (๑) 2019 Walker and Daniels. This is an open-access article distributed under the terms of the Creative Commons Attribution License (CC BY). The use, distribution or reproduction in other forums is permitted, provided the original author(s) and the copyright owner(s) are credited and that the original publication in this journal is cited, in accordance with accepted academic practice. No use, distribution or reproduction is permitted which does not comply with these terms. 